\title{
Foreign Direct Investment and Economic Growth in Africa: Evidence from Oil Exporting Countries
}

\author{
Aderemi Timothy Ayomitunde \\ Department of Economics, Olabisi Onabanjo University, Ogun State, Nigeria \\ Doi: 10.19044/elp.v6no2a2 \\ URL:http://dx.doi.org/10.19044/elp.v6no2a2
}

\begin{abstract}
It has been observed that the catalogue of empirical studies on FDI inflows in Africa in the recent time focused on determinants of FDI inflows in the continent. Meanwhile, the studies that examined the aftermath effects of FDI inflows on the economic growth of the entire continent cannot be totally insulated from heterogeneity problems. Therefore, this paper pooled the first three biggest economies with similar economic structure and examined the relationship between FDI inflows and economic growth in the last 28 years. However, the finding that originated in this study submitted that FDI has a positive relationship with economic growth in the selected countries. The coefficient of FDI shows that a unit change in FDI leads to 5.6138 increment in economic growth of the countries, though not significant at 5\% level of significance. Consequently, due to the findings that emerged in this study, it is expedient that this paper recommends the following; the policy makers in Nigeria, South Africa and Egypt in particular and African continent as a whole should see FDI as a variable that has the potential capacity to propel economic growth of the continent. Therefore, all hands must be on deck by the policy makers in this continent to formulate appropriate policy measures that will create a friendly and attractive investment climate for foreign investors. This in turn will catalyze further inflows of FDI in the continent. Hence, a sustainable growth will be guaranteed in the long run.
\end{abstract}

Keywords: FDI, Economic Growth, Nigeria, South Africa and Egypt.

\subsection{Introduction}

Some decades ago, overseas development assistant was the principal source of foreign capital inflows in Africa. Majority of African countries directly and indirectly depended on this variable for most of their developmental projects. Meanwhile, there has been a paradigm shift in terms of inflows of foreign capital in Africa in the recent time. Foreign direct investment inflows have since 2005 become the principal source of foreign 
capital inflows to Africa. This cross border investment has overtaken overseas development assistance (ODA) in terms of size. Available evidence attests that foreign direct investment contributes about $20 \%$ of fixed capital formation in Africa in the last two decades. However, Africa as a continent is still lagging behind in attracting FDI inflows in the past few decades relative to the other regions of the world. According to (UNCTADstat, 2018), Europe accumulated $49 \%$ of global FDI inflows over the period of 1970 to 2014, and America and Asia attracted $29 \%$ and $20 \%$ concurrently within the same period, meanwhile, $3 \%$ of the global FDI inflows moved to Africa over the same period.

Consequently, the direction and size of this foreign capital has been on the increase but unevenly distributed across countries and sectors in the continent. It has been submitted that 15 oil-rich countries accumulated about $75 \%$ of FDI inflows in Africa (ADBetal, 2011).

As a matter of fact the trend and direction of Africa`s FDI inflows from 1970 till date differ from one sub-region to another. The availability of natural resource endowments in West Africa, North Africa and South Africa have been identified as a major contributory factor that made these sub regions to be the destination of FDI inflows in Africa.

However, the UNCTAD (2006) indicates that FDI inflows to West African sub region in the past decades is principally dominated by inflows to Nigeria. The country received estimated $70 \%$ of the total FDI inflows in subregional block. Similarly, the end of the apartheid regime in South Africa facilitated sporadic inflows of FDI in the country. It is worth of note that, from 1995-99 the Southern Africa's FDI inflow performance rose above the continent's average performance. Despite the negative impact of political instability and corruption on investment climate of the country in the past few years. The industrial revolution that characterized the country has catalyzed the impressive performance the economy registered in the recent time. FDI inflows in the country rose by US\$3.2 approximately $43 \%$ in 2016. (UNCTAD, 2018).

In the same vein, the discovery of gas reserves by foreign multinational companies has orchestrated the dominance of Egypt in North Africa sub region as the principal destination of FDI inflows in the time past. Egypt's FDI inflows rose by $17 \%$ in 2016 which accounted for about estimated $11 \%$ increment of the North Africa`s performance. (UNCTAD, 2018).

Moreover, investment in the productive sectors of the economy would spur growth. The crucial roles in which investment plays in expanding the economic frontiers of nations has sparked off several studies on FDI inflows in Africa. The catalogue of studies on FDI inflows in the continent in the recent time focused on determinants of FDI inflows in the continent. See Ayadi, Ajibolade, Williams and Hymann (2014), Morisset (2000), Asiedu (2006), Chakarabarti (2001), Bende-Nabende (2002), Lemi and Asefa (2002) and 
Anyanwu (2012). However, Nigerian, South African and Egyptian economies have been the biggest economies in the recent years. Despite the fact that several studies have been carried out about the role of foreign capital on economic growth of African economies. These studies cannot be totally insulated from heterogeneity problems. Therefore, this paper pooled the first three biggest economies with similar economic structure together to examine the relationship between FDI inflows and economic growth in the last 28 years. In the literature, there has not been any attempt to pool the three biggest economies in a panel data analysis in the recent time. Hence, the uniqueness of this study.

\subsection{Literature Review}

\subsection{Theoretical Literature Review}

The theoretical framework for this research work is reviewed as follows;

\subsection{Traditional Neoclassical Growth Theory}

Traditional neoclassical models of economic growth came into limelight as a direct outgrowth of the Harrod-Domar and Solow models. The duo models lay emphasis on the paramount role of investment in an economy. The liberalization of national markets invariably draws incremental domestic and foreign investment which consequently increases the rate of capital accumulation in the host economy. Similarly, raising domestic savings rates facilitates capital- labour ratio and per capital incomes in capital-poor developing economies.

The Solow neoclassical growth model in particular is represented as the seminar contribution to the neoclassical theory of growth as a result of this monumental contribution, Robert Solow got the Nobel Prize in Economics. Solow Model expanded the Harrod-Domar model by including a second important economic variable, labour alongside with third independent variable technology, to the growth equation. Consequently, Harrod-Domar model is based on the assumption of the fixed coefficient, constant returns to scale. But the assumption underlining Solow`s neoclassical growth model is diminishing returns to labour and capital separately and constant returns to both factors simultaneously.

\subsection{Empirical literature}

This section presents the extensive review of the selected and relevant literature of FDI inflows in Africa specifically.

While estimating the relationship between religious tension risk, share of oil in exports, level of corruption, domestic credit and FDI inflow in Africa, UNACA (2009) uses a panel data of thirty one African countries between 1984 
and 2009 to argue that religious tension risk, share of oil in exports, size of market, past foreign direct investment inflows, level of corruption and domestic credit are the principal variables that determine net FDI inflows in Africa. In another perspective, Ojo and Alege (2010) estimated a panel data of twenty seven nations in Sub Saharan Africa while examining the impact of global financial crisis, policy implications on sudden rise on FDI inflows, and financial and economic development in Africa. It could be established from the finding of the paper that continuous rise in economic activities propel inflows of FDI in Africa.

However, Chakarabarti (2001) adopted econometric techniques and a range of robustness/sensitivity analysis to analysis the major variables that derive FDI inflows in thirty one African economies. The author submitted that both natural resources and market factors are the major variables that stimulate FDI inflows in Africa.

Consequently, Akinlo (2003) estimated the impact of FDI inflows in Africa with the aid of a panel data analysis of twelve African countries. It was discovered that the impact of FDI inflows was primarily felt by economic growth via accumulation of capital, which was contrary to increasing productivity. While contributing to the literature, Ogun, Egwaikkhide and Ogunleye (2012) estimated the nexus between FDI and real exchange rate in some selected Sub-Saharan Africa (SSA) nations with Granger causality and simultaneous techniques. The researchers found out that FDI flows are sensitive to real exchange rate movements in Sub-Saharan Africa, and a statistically significant relationship exists between the two variables under consideration as well. Similarly, Nyamrunda (2012) estimated Augmented Dickey Fuller test (ADF), Vector error Correction Model (ECM) and the Johansen's cointegration, to assert a significant long-run equilibrium relationship between the exchange rate of Tanzanian shilling and net FDI inflow within the period under consideration. In the same vein, Saibu and Akinbobola (2014) utilized vector error correction modeling (VECM) mechanism in analyzing the link between globalization, FDI and economic growth in some selected Sub Saharan Africa. The paper corroborated that trade liberalization had an insignificant effect on economic growth process of the SSA. And also, the upsurge in the capital flows to African nations was not sufficient enough to prevent the African economies from the global economic shocks.

Furthermore, Adams (2009) contributed to the literature by using OLS analytical framework to investigate the nexus between FDI, domestic investment and economic growth in Sub Saharan African from 1990 to 2003. It was discovered from the study that FDI was positively and significantly correlated with GDP, however, the finding showed an inverse relationship when the country specific effects were factored in. 
Moreover, Gui-Diby (2014) employed GMM technique to investigate FDI inflows and economic growth in 50 countries in Africa between 1980 and 1994. The finding from the GMM estimation confirmed the existence of a negative relationship between FDI and economic growth over the period 19801994, meanwhile positive relationship was the case between 1995 and 2009. The significant improvement in the business environment and the multiplier effect of export on the countries was identified as the contributory factor that orchestrated the positive impact in the latter period of the study.

In conclusion, the empirical studies above showed that literature on FDI inflows in Africa focused more on its determinants. Hence, the relevance of this study.

\subsection{An Overview of the Selected Oil Exporting African Countries}

Table 1: Overview Indicators of the Selected Oil Exporting Countries in Africa (2014)

\begin{tabular}{|c|c|c|c|c|c|c|c|c|}
\hline Country & $\begin{array}{l}\text { FDI } \\
\text { inflows } \\
\% \\
\text { GDP }\end{array}$ & $\begin{array}{l}\text { FDI } \\
\text { inflows } \\
\text { (constant } \\
2005 \\
\text { US\$B) }\end{array}$ & $\begin{array}{l}\text { GDP } \\
\text { (constant } \\
2005 \\
\text { US\$B) }\end{array}$ & $\begin{array}{l}\text { GDP } \\
\text { growth } \\
\text { rate } \\
\%\end{array}$ & $\begin{array}{l}\text { GDP } \\
\text { per capita } \\
\text { (constant } \\
2005 \text { ) US\$ }\end{array}$ & $\begin{array}{l}\text { Population } \\
\text { (M) }\end{array}$ & HDI & $\begin{array}{l}\text { WTO } \\
\text { (Year of } \\
\text { joining) }\end{array}$ \\
\hline Egypt & 1.7 & 4.8 & 286.5 & 2.2 & 3199 & 89.6 & 0.689 & 1995 \\
\hline Nigeria & 0.8 & 4.7 & 568.5 & 6.3 & 3203 & 177.5 & 0.514 & 1995 \\
\hline $\begin{array}{l}\text { South } \\
\text { Africa }\end{array}$ & 1.6 & 5.7 & 350.1 & 1.5 & 6483 & 54 & 0.665 & 1995 \\
\hline
\end{tabular}

Sources: WB, WDI, UNDP, and WTO (2015)

The table above shows the total population of the selected African countries as reported in 2014 with estimated 321.1 million, which comprises $29 \%$ of the Africa`s population. Population is one of the major determinants for market-seeking FDI. Nigeria is the largest country, followed by Egypt and South Africa among the oil exporting countries in Africa. In terms of FDI inflows as a percentage of GDP, Egypt is the highest, followed by South Africa and Nigeria. Meanwhile, South Africa has the highest FDI inflows, followed by Egypt and Nigeria respectively. In terms of the size of the economy, Nigeria is the biggest, followed by South Africa and Egypt concurrently. But the Human Development Index (HDI) is a crucial variable that determines a country`s development levels. This is usually constructed from three subindices: the life expectancy index, education index, and GNI index. Consequently, human development index puts Egypt on top, followed by South Africa and Nigeria respectively. 
Table 2: Composite Risk Index of the Selected Oil Exporting Countries in Africa (2014)

\begin{tabular}{llll} 
Country & $\mathbf{1 9 8 4 - 9 3}$ & $\mathbf{1 9 9 4 - 2 0 0 3}$ & $\begin{array}{l}\mathbf{2 0 0 4 -} \\
\mathbf{2 0 1 4}\end{array}$ \\
\hline Egypt & & & 64.39 \\
Nigeria & 51.20 & 68.57 & 62.14 \\
South Africa & 48.50 & 54.39 & 71.20
\end{tabular}

Source: Authors`Computation from the PRS Group, International Country Risk Guide (2018)

The composite risk index measures a country's overall risk. This is derived from a country's political, economic, and financial risks. This index is normally issued by the PRS Group. However, the index value ranges between a score of 0 and 100.0 connotes a very high risk and 100 a very low risk. Therefore, from the table above, it could be pinpointed that in the last few decades, the South African economy has been characterized with the least risky economy to do business in Africa, followed by Egypt and Nigeria. This indicator is a strategic variable that helps investors to make decision about which economy to invest in.

Table 3: The Worldwide Governance Indicators (WGI) for the Selected Oil Exporting Countries between 2005 and 2014

\begin{tabular}{|c|c|c|c|c|c|c|}
\hline Country & 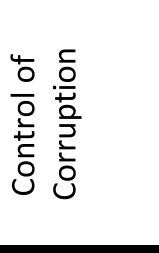 & $\begin{array}{l}3_{0}^{3} \\
\frac{1}{0} \\
\frac{0}{3} \\
\frac{0}{x}\end{array}$ & 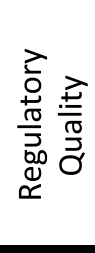 & 苞离 & 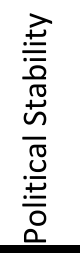 & 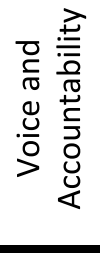 \\
\hline Egypt & -0.6 & -0.3 & -0.4 & -0.6 & -1.0 & -1.1 \\
\hline Nigeria & -1.8 & -1.3 & -0.8 & -1.0 & -2.0 & -0.8 \\
\hline South Africa & 0.1 & 0.1 & 0.5 & 0.4 & 0.1 & 0.6 \\
\hline
\end{tabular}

Source: Authors` Computation from the WGI, 2015

The "Worldwide Governance Indicators" (WGI) advanced by the World Bank in 1996 is comprised of 6 governance indicators for 215 countries. The indicators are as follows: Voice and Accountability, Political Stability and Absence of Violence, Government Effectiveness, Regulatory Quality, Rule of Law and Control of Corruption. It is assumed that the WGI shows the quality of institutions and their impacts on the business environment in host countries. It is worth of note that the value of the index ranges from -2.5 , which implies weak governance performance and 2.5, denoting strong governance performance. 
However, the above table indicates that South Africa shows a relatively better governance performance among the three countries. Nigeria is the worst among the three countries.

Table 4: Ease of Doing Business (Overall Distance to Frontier (DTF)) for the Selected Oil Exporting Countries between 2010 and 2016

\begin{tabular}{lc}
\hline Country & Ease of Doing Business Index (overall rank) \\
\hline Egypt & 56.7 \\
Nigeria & 45.2 \\
South & 68.1 \\
Africa &
\end{tabular}

Source: Authors`Computation from the World Bank's Doing Business project.

In 2002, the World Bank's Doing Business Project inaugurated the Ease of Doing Business index. This index measured the business environment of 189 countries across the world with the following parameters: business regulations and deals mainly with the most relevant procedures needed for foreign companies within the host country. Meanwhile, the index utilizes 10 indicators which are as follows: Starting a Business, Dealing with Construction Permits, Getting Electricity, Registering Property, Getting Credit, Protecting Minority Investors, Paying Taxes, Trading across Borders, Enforcing Contracts, and Resolving Insolvency. Consequently, the World Bank's Doing Business Project annual report on the ease of doing business in 199 countries uses the benchmark output of the quality of the business environment, the country which ranked 1 is considered to have the most friendly business environment, and the country which is ranked 189 is considered to have the least friendly business environment. However, despite the importance of that ranking, it does not provide clear indications about progress of performance, since some countries may achieve progress but that progress may not necessary leads to changes in their ranking. As a result of this, in 2005, the World Bank's Doing Business Project introduced another measurement, tagged "Distance to Frontier" (DTF). It is important to state that this new measurement aids to assess how a specific country improves its business environment. Therefore, the table above indicates that South Africa has the most friendly business environment amongst the three countries, with an average Ease of Doing Business score of 68.1 over the period 2010-2016, followed by Egypt at 56.7 and Nigeria 45.2 concurrently.

\subsection{Methodology Introduction}

This paper utilized secondary data from 1990 to 2017. The data on FDI were sourced from UNCTAD database published by World Bank and data on GDP were extracted from World Bank Development Indicator. The study 
focused on the first three largest economies in Africa which are Nigeria, South Africa and Egypt.

\subsection{Model Specification}

$\mathrm{GDP}=\mathrm{F}(\mathrm{FDI})$

The model 1 can be linearized to form model 2

LnGDP $P_{i t}=\propto_{i}+\beta L n F D I_{i t}+\varepsilon_{i t}$

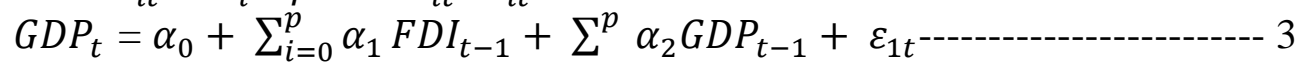

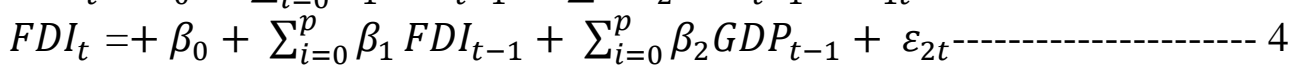

Where $L n G D P_{i t}$ is $\log$ of real GDP to proxy economic growth, $L n F D I_{i t}$ is $\log$ of FDI inflows,. $\quad$ Meanwhile $\propto$

is an intercept and $\beta$ is a slope parameters.

$\mathrm{i}=1 \ldots 3, \mathrm{t}=1990$------------2017.

\section{Table 1: Unit Root Test}

\begin{tabular}{|c|c|c|c|c|c|c|}
\hline \multirow[t]{2}{*}{ Variables } & \multicolumn{3}{|c|}{ ADF - Fisher Chi-square } & \multicolumn{3}{|c|}{ PP - Fisher Chi-square } \\
\hline & @Level & $\begin{array}{l}\text { @First } \\
\text { Difference }\end{array}$ & Remarks & @Level & $\begin{array}{l}\text { @ First } \\
\text { Difference }\end{array}$ & Remarks \\
\hline RGDP & $\begin{array}{l}26.1646 \\
* *\end{array}$ & $* *$ & $\mathrm{I}(0)$ & $\begin{array}{l} \\
3.8679 * *\end{array}$ & $* *$ & I $(0)$ \\
\hline FDI & $\begin{array}{l}2.89146 \\
* *\end{array}$ & $24.0912 * *$ & $\mathrm{I}(1)$ & $\begin{array}{l}3.64109 * \\
*\end{array}$ & $62.3090 * *$ & $\mathrm{I}(1)$ \\
\hline
\end{tabular}

**\%5 level Source; Authors`Computation (2018)

In order to establish the existence or otherwise of stationarity of time series data of the variables adopted for this study, the data were subjected to a unit root test with the aid of the standard Panel Augmented Dickey-Fuller (ADF) and Phillips-Perron (PP) tests. I.e. (ADF - Fisher Chi-square. PP Fisher Chi-square). As the table above indicates, data on FDI has a unit root, but becomes stationary after first differencing. However, real Gross Domestic Product data does not possess a unit root.

Included observations: 84

TABLE 2: Pedroni Residual Cointegration Test

Cross-sections included: 3

Null Hypothesis: No cointegration

Trend assumption: No deterministic trend

User-specified lag length: 1

Newey-West automatic bandwidth selection and Bartlett kernel

Alternative hypothesis: common AR coefs. (within-dimension) Weighted

Panel v-Statistic

Panel rho-Statistic

Panel PP-Statistic

Panel ADF-Statistic

\begin{tabular}{llll} 
Statistic & Prob. & $\begin{array}{l}\text { Weighted } \\
\text { Statistic }\end{array}$ & Prob. \\
\hline \hline-0.231375 & 0.5915 & -0.231375 & 0.5915 \\
0.360344 & 0.6407 & 0.360344 & 0.6407 \\
0.024168 & 0.5096 & 0.024168 & 0.5096 \\
0.456184 & 0.6759 & 0.456184 & 0.6759
\end{tabular}


Alternative hypothesis: individual AR coefs. (between-dimension)

\begin{tabular}{lll} 
& Statistic & Prob. \\
\hline Group rho-Statistic & 1.210860 & 0.8870 \\
Group PP-Statistic & 0.668291 & 0.7480 \\
Group ADF-Statistic & 1.181116 & 0.8812
\end{tabular}

Cross section specific results

\section{Source; Authors`Computation (2018)}

From the table above it could be pinpointed that the variables, real GDP and FDI under consideration for this analysis are I (0) and I (1) respectively. Despite the fact that they may have a deviation in the short run but there is high tendency these variables possess a long run equilibrium relationship. In order to examine the existence or otherwise of the long run equilibrium relationship among these variables, Pedroni Residual Cointegration test was estimated. The results presented in the above table show that there is no cointegration among the variables. In other words, long run equilibrium relationship does not exist among the variables. As a result of this, a panel least square was estimated to examine the impact of FDI on economic growth of the selected oil exporting countries in Africa.

Table 3: Descriptive Statistics of Annual Data Series (1990-2017)

\begin{tabular}{|l|l|l|}
\hline Descriptive Statistics & FDI & RGDP \\
\hline Mean & $3.58 \mathrm{E}+09$ & $7.8 \mathrm{E}+148$ \\
\hline Median & $2.24 \mathrm{E}+09$ & $3.85 \mathrm{E}+13$ \\
\hline Maximum & $8.92 \mathrm{E}+09$ & $2.2 \mathrm{E}+150$ \\
\hline Minimum & $1.00 \mathrm{E}+09$ & $1.96 \mathrm{E}+13$ \\
\hline Std. Deviation & $2.51 \mathrm{E}+09$ & $4.1 \mathrm{E}+149$ \\
\hline Skewness & 0.786992 & 5.003702 \\
\hline Kurtosis & 2.337514 & 26.03704 \\
\hline Jargue-Bera & 10.20710 & 2207.986 \\
\hline Probability & 0.006075 & 0.000000 \\
\hline Sum & $3.01 \mathrm{E}+11$ & $6.5 \mathrm{E}+150$ \\
\hline Sum. Sq. Deviation & $5.21 \mathrm{E}+20$ & $1.4 \mathrm{E}+301$ \\
\hline Observation & 28 & 28 \\
\hline
\end{tabular}

Source; Authors`Computation (2018)

In this section, descriptive statistics of the data has been estimated and presented in the above table. This accounts for the vital information about the sample series such as the mean, median, minimum and maximum values; and the distribution of the sample measured by the skewness, kurtosis and JaqueBera statistics. However, in carrying out econometric analyses, it is important 
to factor in the assumptions of normality and asymptotic properties of data series.

Table 4: Pairwise Dumitrescu Hurlin Panel Causality Tests

Lags: 2

\begin{tabular}{lccc}
\hline \hline Null Hypothesis: & W-Stat. & Zbar-Stat. & Prob. \\
\hline \hline RGDP does not homogeneously cause FDI & 0.72943 & -1.04415 & 0.2964 \\
FDI does not homogeneously cause RGDP & 0.86900 & -0.94576 & 0.3443 \\
\hline \hline
\end{tabular}

Source; Authors`Computation (2018)

This section examines the causal relationship between FDI and economic growth within Pairwise Dumitrescu Hurlin Panel Causality Tests. It could be concluded from the above table that there is no causal relationship between foreign direction investment and economic growth in these countries. This result further confirmed the previous results in table 2 which showed the absence of cointegration between the variables.

Table 4: The Impact of Foreign Direct Investment in Oil Exporting African

Dependent Variable: RGDP

\begin{tabular}{|l|l|l|l|}
\hline Variable & Coefficient & t-statistics & P-value \\
\hline FDI & 5.6138 & 0.21 & 0.8340 \\
\hline \multicolumn{1}{|c|}{ C } & -2.1148 & -0.17 & 0.8622 \\
\hline R-Squared & 0.559 & & \\
\hline Adjusted R-Squared & 0.292 & & \\
\hline Durbin-Watson stat & 2.07 & & \\
\hline
\end{tabular}

Source; Authors` Computation (2018)

The table 4 above indicates that the variable FDI has a positive relationship with economic growth in the selected countries. This result is similarly to the findings of Lumbila (2005), and Ojo and Alege (2010) despite adoption of different methodology. The coefficient of FDI shows that a unit change in FDI leads to 5.6138 rise in economic growth of the countries under consideration, though not significant at $5 \%$ level of significance. By and large, FDI inflows had contributed positively to African economic growth, and this had been the sources of portfolio investment in this continent. Moreover, the explanatory/ independently variable, foreign direct investment explained about $56 \%$ of the systematic variations in the dependent variable, economic growth, leaving $44 \%$ unexplained as result of random chance. This implies that the model is relatively good for the analysis. Meanwhile, after adjusting for the loss in the degree of freedom, the explanatory power reduces to $29 \%$. In the same vein, the value of the Durbin-Watson stat in the table shows the absence of serial correlation in the model. 


\subsection{Conclusion and Recommendations}

This paper has critically investigated the impact of FDI on economic growth in some selected African economies namely, Nigeria, South Africa and Egypt over the period of 1990 to 2017. Consequently, the results of the study are summarized as follows: FDI inflows has a positive impact on economic growth in the selected countries. This implies that FDI inflows have been contributing to the growth of the productive sectors of the economies under consideration in particular and Africa as a whole.

In the same vein, due to the findings that emerged in this study, it is expedient that this paper recommends the following; the policy makers in Nigeria, South Africa and Egypt in particular and African continent as a whole should see FDI as a foreign capital that has the potential capacity to propel economic growth of the continent. Therefore, all hands must be on deck by the policy makers in this continent to formulate appropriate policy measures that will create a friendly and attractive investment climate for foreign investors. This in turn will catalyze further inflows of FDI in the continent. Hence, a sustainable growth will be guaranteed in the long run.

\section{References:}

1. Adams, R. (2004). Economic Growth, Inequality and Poverty: Estimating the Growth Elasticity of Poverty. World Development, 32(12), 1989-2014

2. ADB, OECE, UNDP and UNECA (2011). "African Economic Outlook 2011: Africa and its emerging partners" African Development Bank, Tunis, Tunisia

3. Akinlo, A. E. (2003). 'Foreign Direct Investment and Economic Growth in Sub-Saharan Africa."RISEC; International Review of Economics and Business 50(4) (December): 569-580

4. Asiedu, E. (2006). Foreign Direct Investment in Africa: Role of Government Policy, Institutions and Political Instability. World Economy, 29(1), 63-77.

5. Anyanwu, J.C. (2012). Why does foreign direct investment go where it goes?: New evidence from African Countries. Analysis of Economics and Finance, 13(2); 425-562

6. Ayadi, O.F., Ajibolade, S., Williams, J. \& Hyman, L.M. (2014). Transparency and Foreign Direct Investment into Sub-Saharan Africa: An Econometric Investigation. African Journal of Economic and Management Studies. .5(2)

7. Bende-Nabende, A. (2002). "Foreign Direct Investment Determinants in Sub-Saharan Africa: A Co-Integration Analysis," Economics Bulletin 6 (4): 1-19. 
8. Chakrabati, A. (2001). The determinants of foreign direct investment: Sensitivity analyses of cross country regression. Kyklos, 54(1): 89-11.

9. Domar, E.D. 1946. "Capital Expansion, Rate of Growth and Employment", Econometrica 14: 137-150.

10. Ease of Doing Business data available (www.doingbusiness.org)

11. Gui-Diby S. L. (2014). Impact of Foreign Direct Investment on Economic Growth in Africa: Evidence from three decades of panel data analyses. Research in Economics, 68: 248-256Harrod, R. F. (1948). Towards a Dynamic Economics: Some recent developments of economic theory and their application to policy. London: Macmillan

12. Lumbila, K. N. (2005). What makes FDI work? A panel analysis of the growth effect of FDI in Africa. Africa Region Working Paper Series

13. Morisset, J. (2000). "Foreign Direct Investment in Africa: Policies Also Matter," Transnational Corporations 9 (2): 107-25.

14. Nyamrunda G.C. (2012). Lower Exchange Rates and FDI inflows in Least Developing Economies: Evidence from Tanzania. Advances in Management and applied Economics, 2(4): 1-12.

15. Ojo, J.A.T. \& Alege, P.O. (2010) Global Financial and Macroeconomic Fluctuation-Implication for African Economic Development. African Economic and Business Review. 8(2): 48-82.

16. Ogun, O. Egwaikhide, F. \&Ogunleye, K. (2010). Real Exchange Rate and Foreign Direct investment in Sub-Saharan Africa: Some Empirical Results:Economia Mexicana NUEVA EPOCA, Vol. XXI, num. 1, primer semester de 2012: 175-202.

17. Onyeiwu, S., and Shrestha, H. (2004). Determinants of foreign direct investment in Africa. Journal of Developing Societies, 20: 89-106.

18. Saibu M. \& Akinbobola T. (2014). “Globalization, Foreign Direct Investment and Economic Growth in Sub Saharan Africa“". Journal of Economics and International Finance, 6(3): 62-68.

19. Sichei, M.M., and Kiyondo, G. (2012). Determinants of foreign direct investment in Africa: A panel data Analysis. Global Journal of Management and Business Research. 12(18): 85-96.

20. The PRS Group, International Country Risk Guide Composite Dataset

21. UNECA (2009) the Governance Report, UNECA. Addis Ababa, Ethiopia

22. UNCTAD (2006), World Investment Report 2007: the Shift Towards Services, UNCTAD, Geneva.

23. UNCTAD (2018): Handbook of Statistics, available on-line at (http://www.unctad.org)

24. UNCTAD (2018); World investment Report 2018 published by the United

Nations

on 
TradeandInvestmentavailableatunctad.orgDATA\%20on\%20FDI\%20 BRICS\% 2 01.htm.

25. United Nations Development Programme (UNDP), Human Development Index, available online at: (http://hdr.undp.org/en/composite/HDI

26. World Bank (2018). World Development Indicators. Washington D.C available online at http://data.worldbank.org/data-catalog/worlddevelopmentindicators).

27. Worldwide Governance Indicators (WGI), available online at: (http://info.worldbank.org/governance/wgi/index.aspx\#home)

28. WTO membership data is from the World Trade Organisation (WTO), available online at: (https://www.wto.org/english /thewto_e/whatis_e/tif_e/org6_e.htm. 